\title{
Effect of dietary supplementation with $\beta$-glucan on growth performance and skin-mucus microbiota of sea trout (Salmo trutta)
}

\author{
Olga Revina, Jeḷena Avsejenko, Vjačeslavs Revins, Darius Sargautis, Dina Cīrule, Anda \\ Valdovska
}

Received - 14 April 2020/Accepted - 23 September 2020. Published online: 30 September 2020; ๑Inland Fisheries Institute in Olsztyn, Poland

Citation: Revina O., Avsejenko J., Revins V., Sargautis D., Cirule D., Valdovska A. 2020 - Effect of dietary supplementation with $\beta$-glucan on growth performance and skin-mucus microbiota of sea trout (Salmo trutta) - Fish. Aquat. Life 28: 155-165

\begin{abstract}
This study was performed to determine the effects of dietary supplementation with $\beta$-glucan on the growth performance and skin-mucus microbiota of sea trout, Salmo trutta L. in Latvia. The investigations were performed during an eight-month period (September 2018 - April 2019). A total of 15,000 sea trout were divided into five groups. The experimental fish were fed formulated diets enriched with $1 \mathrm{~g}$ $\mathrm{kg}^{-1} \beta$-glucan (D2), $3 \mathrm{~g} \mathrm{~kg}^{-1} \beta$-glucan (D3), $6 \mathrm{~g} \mathrm{~kg}^{-1}$ biological product BGN-2 (BGN-2) (D4), and $14 \mathrm{~g} \mathrm{~kg}^{-1}$ BGN-2 (D5). The control diet (D1) was not supplemented. Our results showed that fish fed diets D4 and D5 achieved significantly $(\mathrm{P}<0.05)$ higher growth parameters compared to those fed the other diets. Pseudomonas and Aeromonas were detected as the main component of fish skin and gill microbiota. Beta-glucan did not affect the skin-mucus microbiota of the sea trout. All isolates were resistant to amoxicillin, ampicillin, cefalexin, and erythromycin and susceptible to gentamicin. The multiple antibiotic resistance index for all isolates was higher than 0.2.
\end{abstract}

O. Revina [ $\doteq]$, J. Avsejenko, V. Revins, D. Cirule Institute of Food Safety, Animal Health and Environment BIOR, Lejupes Street 3, Riga, LV-1076, Latvia, e-mail: olga.revina@bior.lv

O. Revina, D. Sargautis, A. Valdovska

Latvia University of Life Sciences and Technologies, Lielā Street 2, Jelgava, LV-3004, Latvia
Keywords: Antibiotics, Aquaculture, $\beta$-glucan, Microbiota, Mucus, Sea trout

\section{Introduction}

The sea trout is the anadromous form of the brown trout, Salmo trutta L. that is present in most rivers flowing into the European Atlantic (de Leeuw et al. 2007). Unlike salmon, the range of sea trout feeding migrations in the marine period is the coastal area around the mouths of rivers throughout the post-smolt migration period (Kallio-Nyberg et al. 2006).

The sea trout is a historically significant fish species for Latvia. For more than 130 years Baltic salmon (Salmo salar L.) and sea trout have been reared artificially in Latvia (Purvina et al. 2019). At the present time, the Institute of Food Safety, Animal Health and Environment BIOR (RI BIOR) is engaged in the artificial reproduction and maintenance of the natural sea trout population (Purvina et al. 2019).

According to data from the International Council for the Exploration of the Sea (ICES 2019), the total number of reared sea trout smolts released in 
2018 into the Baltic Sea (SD 22-32) was 3,356,000, which was little less than in the previous year $(3,804,000)$ (ICES 2018) and equal to the previous ten-year average. Latvia released 309,000 smolts in 2018, somewhat less than in $2016(391,000)$ but more than the previous ten-year average $(224,000)$. Aquaculture has become one of the fastest growing sectors in the global food industry (FAO 2018). Unfortunately, along with the intensive development of aquaculture, outbreaks of diseases with huge economic losses have increased dramatically. For the prevention and control of diseases, vaccines, antibiotics, and chemicals are used very widely. The use of medicines, especially antibiotics, is very harmful to aquaculture because of the development of drug-resistant microorganisms, which is also dangerous for human health (Manyi-Loh et al. 2018, Safari and Sarkheil 2018, Cao et al. 2019).

The integument and mucus are the first protective physical and biochemical barriers that inhibit the penetration of pathogens, parasites, and chemical compounds. The integument also performs excretory and osmoregulatory functions, as well as parental feeding (Reverter et al. 2018, Kirschbaum and Formicki 2019, Minniti et al. 2019). The gills are responsible for respiration, osmoregulation, the elimination of ammonia and toxins, $\mathrm{pH}$ balance, and immune defense (Xu et al. 2016). The microbiota of fish gills and skin mucus play important roles in regulating immune and metabolic balance and in the defense against pathogens (Reverter et al. 2017). Bacteria isolated from the skin of fish have antibacterial and antifungal effects against fish pathogens (Lowrey et al. 2015). Changes of mucus microbiota homeostasis leads to a decrease in symbiotic bacteria and an increase of pathogenic bacteria numbers (Boutin et al. 2013).

Immunostimulants are used to improve fish health, increase resistance to diseases, improve growth performance, increase feed efficiency, enhance innate immune responses, and ensure safe aquaculture production for human consumption (Merrifield et al. 2010, Ringø et al. 2011, Song et al. 2014, Vallejos-Vidal et al. 2016, Ringø 2020). Among the various immunostimulants used in aquaculture, one promising candidate is $\beta$-glucan, which is a homopolysaccharide of a glucose molecule linked by a glycosidic bond (Meena et al. 2013) that is usually isolated from cell walls of some plants, mushroom, bacteria, fungi, yeast, and algae (Song et al. 2014, Vallejos-Vidal et al. 2016, Jami et al. 2019, Ringř 2020). The cell wall of the yeast, Saccharomyces cerevisiae, is composed of a $\beta$-linked glucan forming structure with compounds such as mannoproteins, chitin, and some glycoproteins (Ishimoto et al. 2018). The purification method that determine the final properties of $\beta$-glucan plays a crucial role in its effectiveness. Most purification methods rely on $\beta$-glucan insolubility in organic or alkali solvents, following its separation from bounding compounds. However, the compounds removed might demonstrate properties that enhance or supplement $\beta$-glucan performance or act in a different way (Lokesh and Kiron 2016).

Previous studies have shown that dietary supplementation with $\beta$-glucan can be used to positively influenced the growth performance of Baltic salmon under Latvian fish rearing conditions (Medne and Savicka 2003). The aim of our work was to determine the effect of two $\beta$-glucan products derived from yeast, Saccharomyces cerevisiae (a commercial product called Angel Yeast (China) of purified Bglucan and another product called BGN-2 that was derived from yeast through enzymatic hydrolysis comprising Bglucan, nucleotides, amino acids, peptides, and polypeptides) and free mannan developed by JP Biotechnology (Latvia) on growth rates, mortality, changes in the skin and gill mucus microbiota, and its antimicrobial resistance of sea trout in Latvia.

\section{Material and methods}

\section{Experimental fish and culture conditions}

The study was conducted at the Tome state fish farm and the Pelci hatchery of RI BIOR. Pelci is located in the drainage basins of the river Venta, Latvia (565 '16.3" N 21 ${ }^{\circ} 58^{\prime} 28.6^{\prime \prime} \mathrm{E}$ ), and it uses this river 


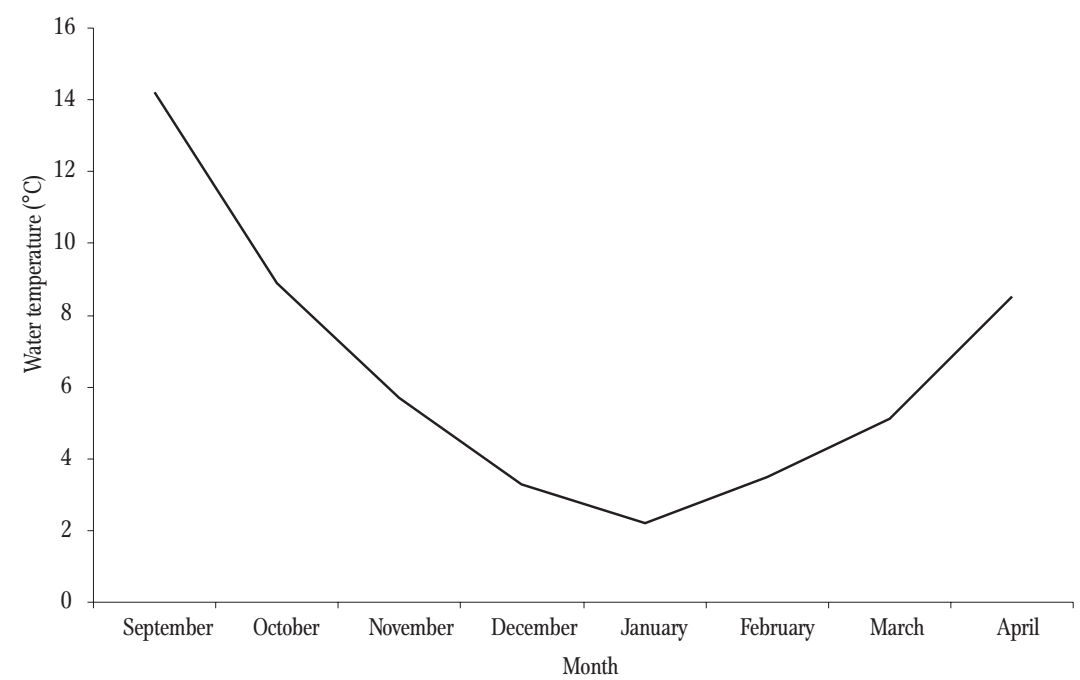

Figure 1. Mean water temperature in flow-through tanks by month.

water. For the rearing trial 15,000 sea trout juveniles $(2.3 \mathrm{~g} \pm 0.30$, mean weight $\pm \mathrm{SE})$ were randomly distributed into five $1.8 \mathrm{~m}^{3}$ tanks $(\mathrm{n}=3000$ in each tank) containing $1.2 \mathrm{~m}^{3}$ water in a flow-through rearing system. The water flow rate was $0.16-0.18 \mathrm{~m} \mathrm{~s}^{-1}$. The water temperature and oxygen level were measured three times daily (08:00, 14:00, and 20:00). The mean water temperature per month is shown in Figure 1. The oxygen level was maintained at 5.5 $10.2 \mathrm{mg} \mathrm{L}^{-1}$ throughout the rearing period.

The fish were acclimated for two weeks, and fish health was assessed regularly. Careful netting and handling were implemented to minimize stress. Prior to the study, the fish had never been treated with antibiotics. All the fish used in this study were subsequently released into natural watercourses in April or May of the same year, according to the Restocking plan of fish resources 2017-2020, Latvia (Regulation of the Cabinet of Ministers No. 684, 2016). The use of the fish in the experiment complied with all relevant local and international animal welfare laws, guidelines, and policies.

\section{Fish diet and preparation of feed}

Fish basal diet was the commercial pelleted feed Aller Futura EX (Aller Aqua, Poland) (which was the appropriate size according to manufacturer recommendations). The proximate composition of the basal diet is listed in Table 1. To prepare immunostimulant diets, $\beta$-glucan (Angel Yeast Co, China; extracted from Saccharomyces cerevisiae), and BGN-2 were added to the basal diet (i.e., the control). The experimental diets were prepared as follows: basal diet (D1), basal diet $+1 \mathrm{~g} \mathrm{~kg}^{-1}$ $\beta$-glucan (D2), basal diet $+3 \mathrm{~g} \mathrm{~kg}^{-1}$ Bglucan (D3), basal diet $+6 \mathrm{~g} \mathrm{~kg}^{-1}$ BGN-2 (D4), basal diet $+14 \mathrm{~g} \mathrm{~kg}^{-1}$ BGN-2 (D5). The diets were coated with rapeseed (Brassica napus) oil and thoroughly mixed with the $\beta$-glucan supplement powder. The pellets were dried in a ventilated room for $1 \mathrm{~h}$ and then placed in the fish feeder. The diets were prepared shortly in advance and were distributed over a four-day period. Every four days a new diet was prepared in order to ensure freshness and quality. Feed was administered with an automatic fish feeder according to a feeding regime of 4 times $\mathrm{h}^{-1}$, with $4 \mathrm{~s}$ feeding time, at approximately $2 \%$ of body weight per day (Ji et al. 2017).

Table 1

Proximate composition of the basal diet fed to sea trout (S. trutta)

\begin{tabular}{ll}
\hline \hline Ingredient & Amount (\% dry weight) \\
\hline \hline Crude protein & 56.0 \\
Crude fat & 18.0 \\
Carbohydrates (NFE) & 7.6 \\
Ashes & 9.0 \\
Fibre & 1.4 \\
\hline \hline
\end{tabular}

\section{Evaluation of growth performance}

Length and weight of 50 fish selected randomly from each tank were measured every 30 days for a period of eight months using a measuring board and an analytical balance $( \pm 0.01)$. Dead fish were collected every day during the study. Growth performance parameters including weight gain (WG), the coefficient of 
variation $(\mathrm{CV})$, size heterogeneity $(\mathrm{SH})$, the specific growth rate (SGR), the feed conversion ratio (FCR), and Fulton's condition factor $(\mathrm{K})$ were calculated (Hopkins 1992, Gjedrem 2005, Gora et al. 2019).

\section{Isolation and identification of bacteria}

The material for bacteriological investigations was mucus samples from the skin and gills of five fish from each group. The mucus samples were collected (September, 2018 - February, 2019) using sterile cotton swabs on an applicator/stick (swab samples). Semisolid Amies transport medium (DELTALAB, S.L., Spain) was used for the transportation of swab samples to the Laboratory of Microbiology and $\mathrm{Pa}-$ thology of RI BIOR. In the laboratory, the swab samples were cultured, according to standard bacteriological procedures by direct cultivation on a double set of plates with a culture medium consisting of tryptone soya agar, blood agar, and MacConkey agar (Biolife, Italy). The plates were incubated in aerobic conditions: one set of plates at $22^{\circ} \mathrm{C}$ and the other set at $37^{\circ} \mathrm{C}$ for 24 to $48 \mathrm{~h}$. After incubation, the different bacterial colonies were sub-cultured onto MacConkey, blood agar, and tryptone soya agar until pure cultures with homogenous colonies were obtained.

The primary identification of cultures was based on the ability of the bacterial colonies to grow at various temperatures, colony morphology, and by phenotypic characteristics using the following tests: catalase, oxidase, indole. Confirmation and identification of bacteria to the species level was performed with a MALDI-TOF Biotyper (Bruker Corporation) and/or the commercially available systems API 20E, API 20NE (BioMérieux, France), or BBL Crystal Enteric/Nonfermenter (Becton Dickinson Microbiology Systems, United Kingdom).

\section{Antimicrobial susceptibility testing}

One isolate of each bacterial culture that was identified to the species level from each sample was selected for determinations of antimicrobial susceptibility.

The antimicrobial susceptibility testing was performed according to the standards of the Clinical and Laboratory Standards Institute (CLSI 2014) using the disk diffusion method. The following antimicrobial paper disks (Bio-Rad, USA) impregnated with a defined concentration of antimicrobial agent were used to determine the antimicrobial susceptibility of the isolates: amoxicillin $(25 \mu \mathrm{g})$, ampicillin $(10 \mu \mathrm{g})$, cefalexin $(30 \mu \mathrm{g})$, doxycycline (30 $\mu \mathrm{g})$, enrofloxacin $(5 \mu \mathrm{g})$, erythromycin $(15 \mu \mathrm{g})$, florfenicol $(30 \mu \mathrm{g})$, gentamicin $(10 \mu \mathrm{g})$, oxytetracycline $(30 \mu \mathrm{g})$, spectinomycin $(100 \mu \mathrm{g})$, streptomycin $(10 \mu \mathrm{g})$, tetracycline $(30 \mu \mathrm{g})$, and trimethoprim $(5 \mu \mathrm{g})$.

Antimicrobial susceptibility testing was performed with one to three bacterial colonies from tryptone soya agar with loopfuls $(1 \mu \mathrm{l})$ that were transferred and suspended in $5 \mathrm{ml}$ tryptic-soya broth (Biolife, Italy). The density of the bacterial suspension, according to MacFarland 0.5, was controlled using a densitometer (Sensititre, TREK Diagnostic Systems Ltd.). The adjusted inoculum suspension was streaked on Mueller Hinton agar or Mueller Hinton Blood agar plates (Ø $90 \mathrm{~mm}$ ) using a sterile cotton swab on an applicator. After three to five minutes, when excess surface moisture had been absorbed by the agar, the antimicrobial disks were positioned on the inoculated agar surface using a 6-Disk dispenser (BioRad, USA). The plates were incubated for 24 to 48 $\mathrm{h}$ to detect antimicrobial resistance in the microorganisms that had grown at a lower temperature ( $A$. salmonicida and others) at $22^{\circ} \mathrm{C}$ and for other microorganisms (A. hydrophila and others) at $37^{\circ} \mathrm{C}$. The diameter of the inhibition zones was measured (mm) after incubation, and the microorganisms were classified as susceptible or resistant according to CLSI breakpoints and manufacturer instructions.

The multiple antibiotic resistance (MAR) index was determined with the procedure described by Krumperman (1983): MAR = a / b, where a represents the number of antibiotics to which the isolate was resistant and $b$ is the total number of antibiotics to which the isolate was exposed. MAR index values higher than 0.2 indicated high potential for contamination. 


\section{Statistical analysis}

All statistical analyses were performed in the R (version 3.6.2) environment with RStudio software. Significant differences were determined using one-way ANOVA, followed by Duncan's multiple range test to compare the differences among the experimental groups and the control group (Aviva and Watson 2013). Differences were considered statistically significant at $\mathrm{P}<0.05$.

\section{Results}

At the beginning of the study (September and October), there was no significant difference in average weight among groups. Weight indicators by month are presented in Table 2. Rapid weight gain was observed from October to November. The fish fed diet D5 had significantly increased $(\mathrm{P}<0.05)$ weight parameters in November and December compared to the nonsupplemented group (D1). From December to February, due to the low water temperature, the fish did not feed and growth ceased (Miller and Harbottle 2018). These changes were observed in group D1. Weight gain stopped and in February was only 11.61 ( \pm 0.63$)$ g. Dietary supplementation with BGN-2 significantly improved the growth of groups D4 and D5 compared to the control group (D1). The weights of the fish in groups D4 and D5 continued to increase even in cold water, and in February it was $17.54( \pm 0.46)$ and $20.19( \pm 0.79) \mathrm{g}$. In April, the final weights of D4 and D5 were $24.38( \pm 1.26)$ and 26.60 $( \pm 1.45) \mathrm{g}$.

Among the dietary groups, significantly lower final weights and total final lengths were observed in the fish fed diets D1 and D2 followed by those fed diets D3, D4, and D5 $(\mathrm{P}<0.05)$. The growth performance parameters are presented in Table 3. There was a visible increasing tendency in weight gain, coefficient of variation, size heterogeneity, and specific growth rate in the fish fed diets D4 and D5 at the end of the trial. Weight gain in groups D1 was $11.92 \mathrm{~g}$, D4 $21.71 \mathrm{~g}$, and D5 $23.85 \mathrm{~g}$. The feed conversion ratio is a very important parameter for fish farmers, and in group D1 the FCR was 2.35, but in groups D4 and D5 it was 1.29 and 1.17, respectively. No significant differences $(\mathrm{P}<0.05)$ in Fulton's condition factor were noted among the different experimental groups. The highest survival rate was observed in fish fed diets D5 (98.40\%) and D4 (97.87\%) (Fig. 2), while the lowest was observed in D1 (92.33\%).

The data presented in Table 4 show that the isolates were mainly represented by Pseudomonas sp. and Aeromonas sp. in all the diet groups. In D1 Pseudomonas sp. was present at 75\%, D2 - $100 \%$, D3 $80 \%$, D4 - $60 \%$, and D5 - 75\%. Aeromonas sp. was present in D3 at 20\%, D4 - $20 \%$, and D5 - $25 \%$.

\section{Table 2}

Mean ( \pm SE) weight of sea trout (S. trutta) diet groups by month. D1 - basal diet, D2 - basal diet $+1 \mathrm{~g} \mathrm{~kg}^{-1} \beta$-glucan, D3 - basal diet $+3 \mathrm{~g} \mathrm{~kg}^{-1}$ Bglucan, D4 - basal diet $+6 \mathrm{~g} \mathrm{~kg}^{-1}$ BGN-2, D5 - basal diet $+14 \mathrm{~g} \mathrm{~kg}^{-1} \mathrm{BGN}-2$

\begin{tabular}{|c|c|c|c|c|c|}
\hline \multirow[b]{2}{*}{ Months } & \multicolumn{5}{|l|}{ Diets } \\
\hline & D1 & D2 & D3 & D4 & D5 \\
\hline September & $2.50 \pm 0.21^{\mathrm{a}}$ & $2.59 \pm 0.17^{\mathrm{a}}$ & $2.67 \pm 0.21^{\mathrm{a}}$ & $2.67 \pm 0.17^{\mathrm{a}}$ & $2.75 \pm 0.16^{\mathrm{a}}$ \\
\hline October & $8.83 \pm 1.03^{\mathrm{a}}$ & $7.93 \pm 0.97^{\mathrm{a}}$ & $9.55 \pm 0.74^{\mathrm{a}}$ & $8.79 \pm 0.68^{\mathrm{a}}$ & $9.02 \pm 0.68^{\mathrm{a}}$ \\
\hline November & $9.71 \pm 0.34^{b}$ & $9.98 \pm 0.68^{\mathrm{ab}}$ & $11.16 \pm 0.36^{\mathrm{ab}}$ & $11.96 \pm 0.55^{\mathrm{ab}}$ & $13.22 \pm 0.38^{\mathrm{a}}$ \\
\hline December & $11.43 \pm 0.56^{\mathrm{c}}$ & $12.60 \pm 0.26^{\mathrm{bc}}$ & $15.37 \pm 1.09^{\mathrm{abc}}$ & $15.94 \pm 0.49^{\mathrm{ab}}$ & $18.79 \pm 0.92^{\mathrm{a}}$ \\
\hline January & $11.84 \pm 0.78^{\mathrm{c}}$ & $13.31 \pm 0.84^{\mathrm{bc}}$ & $16.18 \pm 0.77^{\mathrm{abc}}$ & $16.76 \pm 0.64^{\mathrm{ab}}$ & $19.88 \pm 0.74^{\mathrm{a}}$ \\
\hline February & $11.61 \pm 0.63^{c}$ & $13.72 \pm 0.70^{\mathrm{bc}}$ & $16.40 \pm 0.75^{\mathrm{ab}}$ & $17.54 \pm 0.46^{\mathrm{ab}}$ & $20.19 \pm 0.79^{\mathrm{a}}$ \\
\hline March & $12.80 \pm 0.42^{\mathrm{c}}$ & $14.11 \pm 0.55^{\mathrm{bc}}$ & $17.19 \pm 0.57^{b}$ & $22.01 \pm 0.57^{\mathrm{a}}$ & $24.13 \pm 1.04^{\mathrm{a}}$ \\
\hline April & $14.42 \pm 0.63^{\mathrm{c}}$ & $15.83 \pm 0.65^{\mathrm{c}}$ & $18.40 \pm 0.67^{\mathrm{bc}}$ & $24.38 \pm 1.26^{\mathrm{ab}}$ & $26.60 \pm 1.45^{\mathrm{a}}$ \\
\hline
\end{tabular}

Means with different superscript letters in a row are significantly different $(\mathrm{P}<0.05)$, according to Duncan's multiple range tests 
Table 3

Effects of dietary supplementation with $\beta$-glucan on the growth performance of sea trout (S. trutta). D1 - basal diet, D2 - basal diet $+1 \mathrm{~g} \mathrm{~kg}^{-1} \beta$-glucan, D3 - basal diet $+3 \mathrm{~g} \mathrm{~kg}^{-1} \beta$ glucan, D4 - basal diet $+6 \mathrm{~g} \mathrm{~kg}^{-1}$ BGN-2, D5 - basal diet $+14 \mathrm{~g} \mathrm{~kg}^{-1}$ BGN-2

\begin{tabular}{|c|c|c|c|c|c|}
\hline \multirow[b]{2}{*}{ Parameters } & \multicolumn{5}{|l|}{ Diets } \\
\hline & D1 & D2 & D3 & D4 & D5 \\
\hline Initial weight (g) & $2.50 \pm 0.21^{\mathrm{a}}$ & $2.59 \pm 0.17^{\mathrm{a}}$ & $2.67 \pm 0.21^{\mathrm{a}}$ & $2.67 \pm 0.17^{\mathrm{a}}$ & $2.75 \pm 0.16^{\mathrm{a}}$ \\
\hline Final weight (g) & $14.42 \pm 0.63^{\mathrm{c}}$ & $15.83 \pm 0.65^{\mathrm{c}}$ & $18.40 \pm 0.67^{\mathrm{bc}}$ & $24.38 \pm 1.26^{\mathrm{ab}}$ & $26.60 \pm 1.45^{\mathrm{a}}$ \\
\hline Total final length (cm) & $11.76 \pm 0.34^{\mathrm{a}}$ & $11.91 \pm 0.17^{\mathrm{a}}$ & $12.90 \pm 0.18^{\mathrm{ab}}$ & $13.86 \pm 0.27^{\mathrm{b}}$ & $14.08 \pm 0.17^{\mathrm{b}}$ \\
\hline Weight gain (g) & 11.92 & 13.24 & 15.73 & 21.71 & 23.85 \\
\hline Coefficient of variation (\%) & 18.58 & 17.47 & 15.51 & 21.99 & 23.18 \\
\hline Size heterogeneity (weight) & 0.58 & 0.70 & 0.51 & 0.87 & 1.05 \\
\hline Specific growth rate $\left(\%\right.$ day $\left.^{-1}\right)$ & 0.82 & 0.85 & 0.91 & 1.04 & 1.07 \\
\hline Feed conversion ratio & 2.35 & 2.11 & 1.78 & 1.29 & 1.17 \\
\hline Condition factor $(\mathrm{K})$ & $0.89 \pm 0.04^{\mathrm{a}}$ & $0.93 \pm 0.04^{\mathrm{a}}$ & $0.85 \pm 0.03^{\mathrm{a}}$ & $0.91 \pm 0.05^{\mathrm{a}}$ & $0.95 \pm 0.05^{\mathrm{a}}$ \\
\hline
\end{tabular}

Data are expressed as meana \pm SE. Means with different superscript letters in a row are significantly different $(\mathrm{P}<0.05)$, according to Duncan's multiple range tests

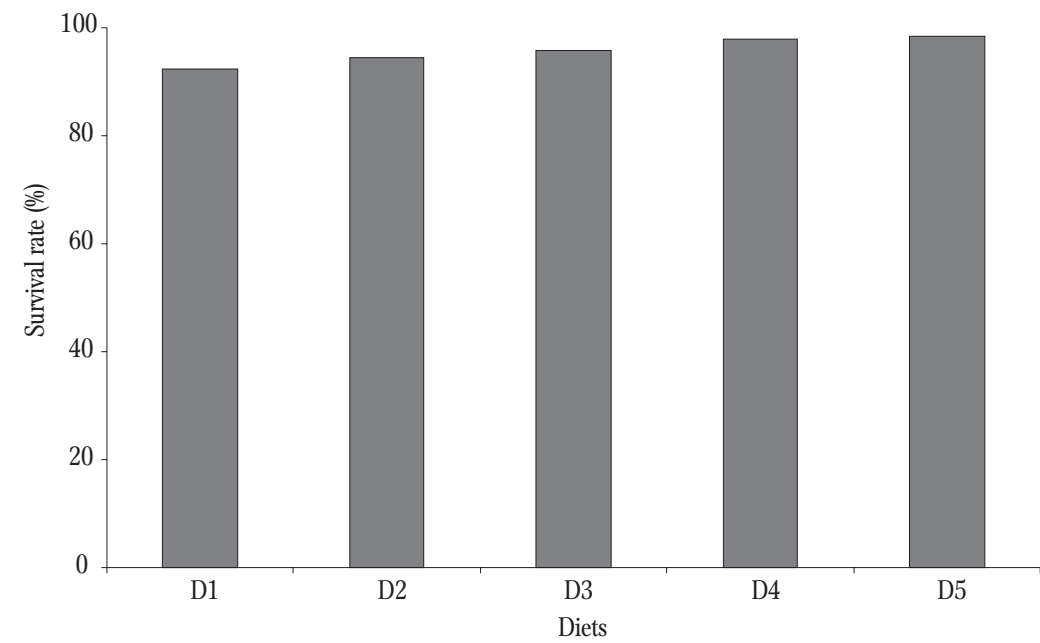

Figure 2. Survival rate of sea trout (S. trutta) in the different experimental groups.

\section{Discussion}

During the juvenile period, sea trout growth is slow (Gjedrem and Gunnes 1978). According to the Restocking plan of fish resources 2017-2020 (Latvia) (The Regulation of the Cabinet of Ministers No. 684, 2016), the Pelci fish hatchery can release sea trout when average weight of the group is $15 \mathrm{~g}$ and that of the smallest fish in the group is $13 \mathrm{~g}$. It is important for Latvian state fish hatcheries to grow high-weight trout on time.

The aquaculture industry depends on the disease resistance, high survival,

Janthinobacterium lividum was isolated in one case from D1 at 25\%. One case was also isolated of Yersinia intermedia from D4 (20\%). All isolates displayed $100 \%$ resistance to amoxicillin, ampicillin, cefalexin, erythromycin, and $100 \%$ susceptibility to gentamicin (Table 4). There were no significant differences in the MAR index among fish diet groups. The MAR index is presented in Table 4. All the isolates showed MAR indexes of more than 0.2. and rapid growth of cultivable species. To achieve these goals various supplements are used, including probiotics, prebiotics, vitamins, herbs, and other immunostimulants. The beneficial effects of yeast or its components have been reported in many studies for salmonids (Øverland and Skrede 2017, Sahlmann et al. 2019). Administering polysaccharides, such as mannan oligosaccharide (MOS) and $\beta$-glucan, improves the growth of many aquaculture species, and it also increases immunological 
Table 4

Isolated bacteria and antimicrobial susceptibility

\begin{tabular}{|c|c|c|c|c|c|c|c|c|c|c|c|c|c|c|c|}
\hline Diets & ISOLATE & AMX & AMP & CEF & DOX & ENR & ERT & FLR & GEN & OXT & SPC & STR & TRT & TRM & MAR \\
\hline \multicolumn{16}{|c|}{ September } \\
\hline D1 & BND & - & - & - & - & - & - & - & - & - & - & - & - & - & - \\
\hline D2 & $\begin{array}{l}\text { Pseudomonas putida, } \\
\text { P.oryzihabitans }\end{array}$ & $\mathrm{R}$ & $\mathrm{R}$ & $\mathrm{R}$ & S & S & $\mathrm{R}$ & $\mathrm{R}$ & S & S & S & $\mathrm{R}$ & S & $\mathrm{R}$ & 0.54 \\
\hline D3 & $\begin{array}{l}\text { Aeromonas } \\
\text { hydrophyla, A.sobria }\end{array}$ & $\mathrm{R}$ & $\mathrm{R}$ & $\mathrm{R}$ & S & S & $\mathrm{R}$ & S & S & S & S & $\mathrm{R}$ & $S$ & $\mathrm{R}$ & 0.46 \\
\hline D4 & A.sorbia & $\mathrm{R}$ & $\mathrm{R}$ & $\mathrm{R}$ & S & S & $\mathrm{R}$ & S & S & S & S & $\mathrm{R}$ & S & $\mathrm{R}$ & 0.46 \\
\hline D5 & $\begin{array}{l}\text { P.fluorescens, } \\
\text { P.savastanoi }\end{array}$ & $\mathrm{R}$ & $\mathrm{R}$ & $\mathrm{R}$ & S & S & $\mathrm{R}$ & $\mathrm{R}$ & S & S & S & $\mathrm{R}$ & S & $\mathrm{R}$ & 0.54 \\
\hline \multicolumn{16}{|c|}{ October } \\
\hline D1 & BND & - & - & - & - & - & - & - & - & - & - & - & - & - & - \\
\hline D2 & $\begin{array}{l}\text { BND } \\
\text { P.chlororaphis, }\end{array}$ & - & - & - & - & - & - & - & - & - & - & - & - & - & - \\
\hline D3 & $\begin{array}{l}\text { P.koreensis, } \\
\text { P.gessardii } \\
\text { P.chlororaphis, }\end{array}$ & $\mathrm{R}$ & $\mathrm{R}$ & $\mathrm{R}$ & $\mathrm{R}$ & S & $\mathrm{R}$ & $\mathrm{R}$ & S & $\mathrm{R}$ & $\mathrm{R}$ & $\mathrm{R}$ & $\mathrm{R}$ & $\mathrm{R}$ & 0.85 \\
\hline D4 & $\begin{array}{l}\text { P.koreensis, } \\
\text { P.gessardii } \\
\text { P.chlororaphis, }\end{array}$ & $\mathrm{R}$ & $\mathrm{R}$ & $\mathrm{R}$ & $\mathrm{R}$ & S & $\mathrm{R}$ & $\mathrm{R}$ & S & $\mathrm{R}$ & $\mathrm{R}$ & $\mathrm{R}$ & $\mathrm{R}$ & $\mathrm{R}$ & 0.85 \\
\hline D5 & $\begin{array}{l}\text { P.koreensis, } \\
\text { P.gessardii }\end{array}$ & $\mathrm{R}$ & $\mathrm{R}$ & $\mathrm{R}$ & $\mathrm{R}$ & S & $\mathrm{R}$ & $\mathrm{R}$ & S & $\mathrm{R}$ & $\mathrm{R}$ & $\mathrm{R}$ & $\mathrm{R}$ & $\mathrm{R}$ & 0.85 \\
\hline \multicolumn{16}{|c|}{ November } \\
\hline D1 & P.fluorescens & $\mathrm{R}$ & $\mathrm{R}$ & $\mathrm{R}$ & $S$ & $\mathrm{~S}$ & $\mathrm{R}$ & $\mathrm{R}$ & S & $\mathrm{R}$ & $\mathrm{R}$ & $\mathrm{R}$ & $\mathrm{R}$ & $\mathrm{R}$ & 0.77 \\
\hline D2 & P.fluorescens, P.putida & $\mathrm{R}$ & $\mathrm{R}$ & $\mathrm{R}$ & S & $\mathrm{S}$ & $\mathrm{R}$ & $\mathrm{R}$ & S & $S$ & $\mathrm{R}$ & $\mathrm{R}$ & $\mathrm{S}$ & $\mathrm{R}$ & 0.62 \\
\hline D3 & P.fluorescens & $\mathrm{R}$ & $\mathrm{R}$ & $\mathrm{R}$ & $\mathrm{R}$ & $\mathrm{R}$ & $\mathrm{R}$ & $\mathrm{R}$ & $\mathrm{S}$ & $\mathrm{R}$ & $\mathrm{R}$ & $\mathrm{R}$ & $\mathrm{R}$ & $\mathrm{R}$ & 0.92 \\
\hline D4 & P.fluorescens & $\mathrm{R}$ & $\mathrm{R}$ & $\mathrm{R}$ & $S$ & $\mathrm{~S}$ & $\mathrm{R}$ & $S$ & $S$ & $\mathrm{R}$ & $\mathrm{R}$ & $S$ & $S$ & $\mathrm{R}$ & 0.54 \\
\hline D5 & A.hydrophila & $\mathrm{R}$ & $\mathrm{R}$ & $\mathrm{R}$ & $S$ & $\mathrm{~S}$ & $\mathrm{R}$ & $\mathrm{R}$ & $S$ & $\mathrm{R}$ & $\mathrm{R}$ & $\mathrm{R}$ & $\mathrm{R}$ & $\mathrm{R}$ & 0.77 \\
\hline \multicolumn{16}{|c|}{ December } \\
\hline D1 & P.cepacia & $\mathrm{R}$ & $\mathrm{R}$ & $\mathrm{R}$ & $S$ & $\mathrm{~S}$ & $\mathrm{R}$ & $\mathrm{R}$ & S & S & $\mathrm{R}$ & $S$ & $S$ & - & 0.50 \\
\hline D2 & P.cepacia & $\mathrm{R}$ & $\mathrm{R}$ & $\mathrm{R}$ & S & $\mathrm{S}$ & $\mathrm{R}$ & $\mathrm{R}$ & S & $S$ & $\mathrm{R}$ & $S$ & $S$ & - & 0.50 \\
\hline D3 & P.cepacia & $\mathrm{R}$ & $\mathrm{R}$ & $\mathrm{R}$ & $\mathrm{R}$ & $\mathrm{R}$ & $\mathrm{R}$ & $\mathrm{R}$ & S & $\mathrm{R}$ & $\mathrm{R}$ & $\mathrm{R}$ & $\mathrm{R}$ & - & 0.92 \\
\hline D4 & P.cepacia & $\mathrm{R}$ & $\mathrm{R}$ & $\mathrm{R}$ & $\mathrm{R}$ & $\mathrm{R}$ & $\mathrm{R}$ & $\mathrm{R}$ & $S$ & $\mathrm{R}$ & $\mathrm{R}$ & $\mathrm{R}$ & $\mathrm{R}$ & - & 0.92 \\
\hline D5 & BND & - & - & - & - & - & - & - & - & - & - & - & - & - & - \\
\hline \multicolumn{16}{|c|}{ January } \\
\hline D1 & P.fluorescens, P.putida & $\mathrm{R}$ & $\mathrm{R}$ & $\mathrm{R}$ & S & $S$ & $\mathrm{R}$ & $S$ & S & $S$ & S & $S$ & S & $\mathrm{R}$ & 0.38 \\
\hline D2 & BND & - & - & - & - & - & - & - & - & - & - & - & - & - & - \\
\hline D3 & BND & - & - & - & - & - & - & - & - & - & - & - & - & - & - \\
\hline D4 & BND & - & - & - & - & - & - & - & - & - & - & - & - & - & - \\
\hline D5 & BND & - & - & - & - & - & - & - & - & - & - & - & - & - & - \\
\hline \multicolumn{16}{|c|}{ February } \\
\hline D1 & $\begin{array}{l}\text { Janthinobacterium } \\
\text { lividum }\end{array}$ & $\mathrm{R}$ & - & $\mathrm{R}$ & S & $S$ & $\mathrm{R}$ & S & S & $\mathrm{R}$ & $\mathrm{R}$ & $\mathrm{R}$ & $\mathrm{R}$ & S & 0.58 \\
\hline D2 & BND & - & - & - & - & - & - & - & - & - & - & - & - & - & - \\
\hline D3 & $\begin{array}{l}\text { P.veronii, P.congeals, } \\
\text { P.migulae }\end{array}$ & $\mathrm{R}$ & - & $\mathrm{R}$ & S & S & $\mathrm{R}$ & $\mathrm{R}$ & - & S & $\mathrm{R}$ & $\mathrm{R}$ & $\mathrm{R}$ & $\mathrm{R}$ & 0.73 \\
\hline D4 & Yersinia intermedia & $\mathrm{R}$ & - & $\mathrm{R}$ & $S$ & $\mathrm{~S}$ & $\mathrm{R}$ & $S$ & $S$ & $S$ & $S$ & $S$ & $S$ & $S$ & 0.25 \\
\hline D5 & Pseudomonas sp. & $\mathrm{R}$ & - & $\mathrm{R}$ & $S$ & $\mathrm{~S}$ & $\mathrm{R}$ & $\mathrm{R}$ & $S$ & $\mathrm{~S}$ & $\mathrm{R}$ & $\mathrm{S}$ & $\mathrm{S}$ & $\mathrm{R}$ & 0.50 \\
\hline
\end{tabular}

$\mathrm{BND}=$ Bacteria were not detected. $\mathrm{R}=$ Resistant; $\mathrm{S}=$ Susceptible. AMX = Amoxicillin; $\mathrm{AMP}=\mathrm{Ampicillin} ; \mathrm{CEF}=\mathrm{Cefalexin}$; DOX = Doxycycline; ENR = Enrofloxacin; ERT = Erythromycin; FLR = Florfenicol; GEN = Gentamicin; OXT = Oxytetracycline; $\mathrm{SPC}=$ Spectinomycin; STR $=$ Streptomycin; TRT $=$ Tetracycline; TRM $=$ Trimethoprim. MAR = Multiple antibiotic resistance index 
responses, intestinal microbiota, and disease resistance (Do Huu et al. 2016, Mohan et al. 2019).

Our research also proved the beneficial effects of the $\beta$-glucan dietary supplement on the growth performance and survival of sea trout. Especially good results were obtained with BGN-2 $\left(14 \mathrm{~g} \mathrm{~kg}^{-1}\right)$. It is important to consider the dose since dietary supplementation with pure $\beta$-glucan at $1 \mathrm{~g} \mathrm{~kg}^{-1}$ and 3 $\mathrm{g} \mathrm{kg}^{-1}$ did not provide the expected results. Studies have also indicated a lack of positive effects on the growth of crucian carp, Carassius carassius (L.), Nile tilapia, Oreochromis niloticus (L.), and sea bass, Dicentrarchus labrax (L.) (Cao et al. 2019). Ji et al. (2017) proved that administering dietary $\beta$-glucan can contribute to the growth of rainbow trout at a dose of $2 \mathrm{~g} \mathrm{~kg}^{-1}$. SGR, WG, and survival rates were significantly improved by increasing the $\beta$-glucan dose. Data analysis revealed no statistically significant differences in condition factor among the treatment groups at the end of trial. Similar results were obtained by other researchers (Nieves-Rodríguez et al. 2018).

Epidermis, scales, and mucus create a protective immunological and physical barrier between the fish and the surrounding environment. The mucosal barriers of the gills, skin, and alimentary tract are parts of the innate immune response of fishes (Mohan et al. 2019). The microbiota is a community of microorganisms that occupy a particular ecosystem and have important biological roles (Lowrey et al. 2015). The composition of the mucosal microbiota depends on fish species, water temperature, habitat, and the immunological status of the host (Wilson et al. 2008, Larsen et al. 2013). There are many studies related to the intestinal microbiota of fishes, but the microbiota of skin and gill mucus is not well understood (Larsen et al. 2013, Lowrey et al. 2015). Not enough studies have focused on the effects of $\beta$-glucan dietary supplements on the skin and gill mucus microbiota. However, it is known that different dietary intakes might affect the abundance of fish skin mucus microbial communities (Landeira-Dabarca et al. 2013).

Proteobacteria, Firmicutes, and Actinobacteria were the predominant phylum, and Bacteroidetes and Cyanobacteria were also identified (Larsen et al. 2013, Reverter et al. 2017). Previous studies showed that gill mucus was represented by the families Vibrionaceae, Pseudomonadaceae, and Hahellaceae (Reverter et al. 2018). Using various methods, some scientists recognized Pseudomonas as the main component of fish skin microbiota, and our results confirmed this. In aquaculture, $P$. fluorescens and $P$. putida are considered to be opportunistic pathogens (Altinok et al. 2006). It is important to remember that opportunistic pathogenic bacteria under stress conditions can lead to outbreaks of bacterial infections (Altinok et al. 2006, Sreedharan et al. 2012, Avdeeva 2017). Aeromonas sp. is a ubiquitous aquatic bacteria that can cause diseases in several species of animals, including fish and humans, especially when immunity is weakened.

Gammaproteobacteria were mainly represented by the families Pseudomonadaceae and Aeromonadaceae isolated from the skin and gill mucus of sea trout. Only in one case was the family Yersiniaceae identified, and it was represented by Yersinia intermedia. This family is a member of the order Enterobacterales in the class Gammaproteobacteria of the phylum Proteobacteria (Adeolu et al. 2016). Table 4 indicates that in January $P$. fluorescens and $P$. putida were only isolated in group D1. In other groups, these bacteria were not detected in the isolates. This can be explained by the fact that the lowest water temperature was in January (Fig. 1). Low water temperature primarily influences microbial metabolic rates that is generally expressed as growth rates. The lower the temperature, the lower the growth rates (Hülsen et al. 2016).

Antimicrobial resistance is a global public health threat, and in natural surface waters it is difficult to find areas where antibiotics cannot be detected (Yang and Carlson 2003). There are studies that prove that bacteria are becoming/ have become//??? resistant to all known antibiotics (Rasul and Majumdar 2017). Studies from all over the world indicate that the number of multiresistant Aeromonas sp. isolated from freshwater fish is increasing (Sreedharan et al. 2012), and our results confirm this. In the genera Aeromonas, Yersinia, 
Photobacterium, Edwardsiella, and Vibrio resistant genes have been found on transferable plasmids, transposons and integrons (Sreedharan et al. 2012, Miller and Harbottle 2018). Scientists from Japan have proved that the tetracycline resistance of marine strains of Photobacterium, Vibrio, Alteromonas, and Pseudomonas can be transferred to Escherichia coli by conjugation (Rasul and Majumdar 2017). A MAR index of 0.2 or more is said to have originated from high risk sources of contamination (Sreedharan et al. 2012).

Based on our results, we assume that $\beta$-glucan did not affect the skin and gill mucus microbiota diversity of sea trout in terms of the microbial community of the microbiota. Further research regarding the antibiotic resistance of genes is necessary. Our study also indicated that $\beta$-glucan had an advantageous impact on the growth and survival of sea trout fingerlings and smolts. Supplementing feed with $\beta$-glucan from BGN-2 at doses of 6 and $14 \mathrm{~g}$ $\mathrm{kg}^{-1}$ diet was a sufficient amount to increase growth performance and reduce mortality. These doses can be recommended to help achieve good success in sea trout rearing under Latvian conditions, especially in the winter months.

Acknowledgments. The present study was supported financially by the research project "Strengthening the Scientific Capacity of LLU” No. Z-27 - The application of $\beta$-glucan to ensure of sea trout health.

Author contributions. O.R., D.C., A.V., V.R., and D.S. designed the research. O.R. and V.R. performed the research and statistical analysis. J.A. was responsible for the isolation and identification of the bacteria and antimicrobial susceptibility testing. D.S. produced the BGN-2. All of the authors were involved in formulating the results, the manuscript draft, and approved the final manuscript.

ORCID ID

Vjačeslavs Revins (iD https://orcid.org/0000-0001-5042-3309

\section{References}

Adeolu M., Alnajar S., Naushad S., Gupta R.S. 2016 Genome-based phylogeny and taxonomy of the 'Enterobacteriales': Proposal for enterobacterales ord. nov. divided into the families Enterobacteriaceae, Erwiniaceae fam. nov., Pectobacteriaceae fam. nov., Yersiniaceae fam. nov., Hafniaceae fam. nov., Morgane Int. J. Syst. Evol. Microbiol. 66: 5575-5599.

Altinok I., Kayis S., Capkin E. 2006 - Pseudomonas putida infection in rainbow trout - Aquaculture 261: 850-855.

Avdeeva E. 2017 - Conditionally pathogenic bacteria of fish in natural and artificial reservoirs of the Kaliningrad region - Trudy VNIRO 167: 104-109 (in Russian).

Aviva P., Watson P. 2013 - Statistics for Veterinary and Animal Science, 3rd edition - Wiley-Blackwell, British Medical Journal Publishing Group, 392 p.

Boutin S., Audet C., Derome N. 2013 - Probiotic treatment by indigenous bacteria decreases mortality without disturbing the natural microbiota of Salvelinus fontinalis - Can. J. Microbiol. 59: 662-670.

Cao H., Yu R., Zhang Y., Hu B., Jian S., Wen C., Kajbaf K., Kumar V., Yang G. 2019 - Effects of dietary supplementation with $\beta$-glucan and Bacillus subtilis on growth, fillet quality, immune capacity, and antioxidant status of Pengze crucian carp (Carassius auratus var. Pengze) - Aquaculture 508: 106-112.

CLSI 2014 - Performance Standards for Antimicrobial Susceptibility Testing of Bacteria Isolated From Aquatic Animals; Second Informational Supplement.

Do Huu H., Sang H.M., Thanh Thuy N.T. 2016 - Dietary $\beta$-glucan improved growth performance, Vibrio counts, haematological parameters and stress resistance of pompano fish, Trachinotus ovatus Linnaeus, 1758 - Fish Shellfish Immunol. 54: 402-410.

FAO 2018 - The State of World Fisheries and Aquaculture 2018 - Meeting the sustainable development goals, Rome, Italy.

Gjedrem T. 2005 - Selection and breeding programs in aquaculture - Springer, Dordrecht, Netherlands, 364 p.

Gjedrem T., Gunnes K. 1978 - Comparison of growth rate in Atlantic salmon, pink salmon, Arctic char, sea trout and rainbow trout under Norwegian farming conditions Aquaculture 13: 135-141.

Gora A.H., Ambasankar K., Sandeep K.P., Rehman S., Agarwal D., Ahmad I., Ramachandran K. 2019 - Effect of dietary supplementation of crude microalgal extracts on growth performance, survival and disease resistance of Lates calcarifer (Bloch, 1790) larvae - Indian J. Fish. 66: 64-72.

Hopkins K. 1992 - Reporting Fish Growth: A Review of the Basics - J. World Aquacult. Soc. 23: 173-179. 
Hülsen T., Barry E.M., Lu Y., Puyol D., Batstone D.J. 2016 Low temperature treatment of domestic wastewater by purple phototrophic bacteria: Performance, activity, and community - Water Res. 100: 537-545.

ICES 2018 - Report of the Baltic Salmon and Trout Assessment Working Group (WGBAST), 20-28 March 2018, Turku, Finland, ICES CM 2018/ACOM:10, 369 p.

ICES 2019 - Baltic Salmon and Trout Assessment Working Group (WGBAST) - ICES Scientific Reports. 1:23, 312 p.

Ishimoto Y., Ishibashi K., Yamanaka D., Adachi Y., Kanzaki K., Iwakura Y., Ohno N. 2018 - Production of low-molecular weight soluble yeast $\beta$-glucan by an acid degradation method - Int. J. Biol. Macromol. 107: 2269-2278.

Jami M.J., Abedian Kenari A., Paknejad H., Mohseni M. 2019 - Effects of dietary b-glucan, mannan oligosaccharide, Lactobacillus plantarum and their combinations on growth performance, immunity and immune related gene expression of Caspian trout, Salmo trutta caspius (Kessler, 1877) - Fish Shellfish Immunol. 91: 202-208.

Ji L., Sun G., Li J., Wang Y., Du Y., Li X., Liu Y. 2017 - Effect of dietary $\beta$-glucan on growth, survival and regulation of immune processes in rainbow trout (Oncorhynchus mykiss) infected by Aeromonas salmonicida' - Fish Shellfish Immunol. 64: 56-67.

Kallio-Nyberg I., Jutila E., Jokikokko E., Saloniemi I. 2006 Survival of reared Atlantic salmon and sea trout in relation to marine conditions of smolt year in the Baltic Sea Fish. Res. 80: 295-304.

Kirschbaum F., Formicki K. 2019 - The Histology of Fishes CRC Press LLC, Boca Raton, FL, 448 p.

Krumperman P.H. 1983 - Multiple antibiotic resistance indexing of Escherichia coli to identify high-risk sources of fecal contamination of foods - Appl. Environ. Microbiol. 46: 165-170.

Landeira-Dabarca A., Sieiro C., Álvarez M. 2013 - Change in food ingestion induces rapid shifts in the diversity of microbiota associated with cutaneous mucus of Atlantic salmon Salmo salar - J. Fish Biol. 82: 893-906.

Larsen A., Tao Z., Bullard S.A., Arias C.R. 2013 - Diversity of the skin microbiota of fishes: evidence for host species specificity - FEMS Microbiol. Ecol. 85: 483-494.

de Leeuw J.J., ter Hofstede R., Winter H.V. 2007 - Sea growth of anadromous brown trout (Salmo trutta) - J. Sea Res. 58: $163-165$

Lokesh J., Kiron V. 2016 - Transition from freshwater to seawater reshapes the skin-associated microbiota of Atlantic salmon - Sci. Rep. 6: 19707.

Lowrey L., Woodhams D.C., Tacchi L., Salinas I. 2015 - Topographical mapping of the rainbow trout (Oncorhynchus mykiss) microbiome reveals a diverse bacterial community with antifungal properties in the skin - Appl. Environ. Microbiol. 81: 6915-6925.
Manyi-Loh C., Mamphweli S., Meyer E., Okoh A. 2018 - Antibiotic use in agriculture and its consequential resistance in environmental sources: potential public health implications - Molecules 23: 795.

Medne R., Savicka I. 2003 - Promotion of salmon rearing efficiency by including yeast extract Aqualase Two in the diet - Acta Univ. Latv. Ser. Biol. 662: 45-50.

Meena D.K., Das P., Kumar S., Mandal S.C., Prusty A.K., Singh S.K., Akhtar M.S., Behera B.K., Kumar K., Pal A.K., Mukherjee S.C. 2013 - Beta-glucan: an ideal immunostimulant in aquaculture (a review) - Fish Physiol. Biochem. 39: 431-457.

Merrifield D.L., Dimitroglou A., Foey A., Davies S.J., Baker R.T.M., Bøgwald J., Castex M., Ringø E. 2010 - The current status and future focus of probiotic and prebiotic applications for salmonids - Aquaculture 302:1-18.

Miller R.A., Harbottle H. 2018 - Antimicrobial Drug Resistance in Fish Pathogens - Microbiol. Spectr. 6: 501-520.

Minniti G., Sandve S.R., Padra J.T., Hagen L.H., Lindén S., Pope P.B., Arntzen M., Vaaje-Kolstad G. 2019 - The farmed Atlantic salmon (Salmo salar) skin-mucus proteome and its nutrient potential for the resident bacterial community - Genes 10: 515.

Mohan K., Ravichandran S., Muralisankar T., Uthayakumar V., Chandirasekar R., Seedevi P., Rajan D.K. 2019 Potential uses of fungal polysaccharides as immunostimulants in fish and shrimp aquaculture: A review - Aquaculture 500: 250-263.

Nieves-Rodríguez K., Álvarez-González C., Peńa-Marín E., Vega-Villasante F., Martínez-García R., Camarillo-Coop S., Tovar-Ramírez D., Guzmán-Villanueva L., Andree K., Gisbert E. 2018 - Effect of $\beta$-glucans in diets on growth, survival, digestive enzyme activity, and immune system and intestinal barrier gene expression for tropical gar (Atractosteus tropicus) juveniles - Fishes 3: 27.

Øverland M., Skrede A. 2017 - Yeast derived from lignocellulosic biomass as a sustainable feed resource for use in aquaculture - J. Sci. Food Agric. 97: 733-742.

Purvina S., Medne R., Bajinskis J., Kondratyeva N. 2019 Success of long term salmonid restocking in Latvia Environ. Exp. Biol. 17: 31-32.

Rasul M.G., Majumdar B.C. 2017 - Abuse of Antibiotics in Aquaculture and it's Effects on Human, Aquatic Animal and Environment - Saudi J. Life Sci. 2: 81-88.

Reverter M., Sasal P., Tapissier-Bontemps N., Lecchini D., Suzuki M. 2017 - Characterisation of the gill mucosal bacterial communities of four butterflyfish species: a reservoir of bacterial diversity in coral reef ecosystems FEMS Microbiol. Ecol. 93: fix051.

Reverter M., Tapissier-Bontemps N., Lecchini D., Banaigs B., Sasal P. 2018 - Biological and ecological roles of external fish mucus: a review - Fishes 3: 41.

Ringø E. 2020 - Probiotics in shellfish aquaculture - Aquac. Fish. 5: 1-27. 
Ringø E., Erik Olsen R., Gonzalez Vecino J.L., Wadsworth S. 2011 - Use of Immunostimulants and Nucleotides in Aquaculture: A Review - J. Marine Sci. Res. Development 1: 104 .

Safari O., Sarkheil M. 2018 - Dietary administration of eryngii mushroom (Pleurotus eryngii) powder on haemato-immunological responses, bactericidal activity of skin mucus and growth performance of koi carp fingerlings (Cyprinus carpio koi) - Fish Shellfish Immunol. 80: 505-513.

Sahlmann C., Djordjevic B., Lagos L., Mydland L.T., Morales-Lange B., Øvrum Hansen J., Ånestad R., Mercado L., Bjelanovic M., Press C.M.L., Øverland M. 2019 - Yeast as a protein source during smoltification of Atlantic salmon (Salmo salar L.), enhances performance and modulates health - Aquaculture 513: 734396.

Song S.K., Beck B.R., Kim D., Park J., Kim J., Kim H.D., Ringø E. 2014 - Prebiotics as immunostimulants in aquaculture: A review - Fish Shellfish Immunol. 40: 40-48.
Sreedharan K., Philip R., Singh I.S.B. 2012 - Virulence potential and antibiotic susceptibility pattern of motile aeromonads associated with freshwater ornamental fish culture systems: A possible threat to public health - Braz. J. Microbiol. 43: 754-765.

The Regulation of the Cabinet of Minister No. 684, 2016 Restocking plan of fish resources 2017-2020 - Latv. Vçstnesis, Nr. 227.

Vallejos-Vidal E., Reyes-López F., Teles M., MacKenzie S. 2016 - The response of fish to immunostimulant diets Fish Shellfish Immunol. 56: 34-69.

Xu Z., Takizawa F., Parra D., Gómez D., Von Gersdorff Jørgensen L., Lapatra S.E., Sunyer J.O. 2016 - Mucosal immunoglobulins at respiratory surfaces mark an ancient association that predates the emergence of tetrapods Nat. Commun. 7: 1-14.

Yang S., Carlson K. 2003 - Evolution of antibiotic occurrence in a river through pristine, urban and agricultural landscapes - Water Res. 37: 4645-4656. 